Article

\title{
The Use of the Present Perfect (pretérito perfecto compuesto) with Aoristic Value in the Speech of Latin American Students
}

\author{
Rosana Ariolfo \\ Department LeLiA, University of Bari, 70121 Bari, Italy; rosanaariolfo@yahoo.com
}

Received: 25 April 2019; Accepted: 29 May 2019; Published: 3 June 2019

\begin{abstract}
This article focuses on the use of the present perfect (he cantado) with aoristic value, or rather, on pre-hodiernal contexts in which, as a rule, the simple form (canté) should appear. This verbal form is examined on the basis of a corpus of semi-guided interviews provided to Latin American students living in Genoa and taking into account its characteristics, the syntactic environment in which it is used, combinations with other verb forms, adverbial complements, temporal expressions, deixis and the communicative context in which it is inserted. This phenomenon has already been analyzed in several recent studies carried out by Azpiazu, Kempas, Montoro del Arco, Bermejo Calleja and Soto, both in European and American contexts, and has led to the conclusion that it could be related to discursive strategies of the speaker as well as to a convergence towards the local language (i.e., Italian).
\end{abstract}

Keywords: past simple; present perfect; aorist; American Spanish; Latin American immigration; orality

\section{Introduction}

\subsection{Values of the Pretérito Perfecto Compuesto in the Spanish Language in Spain and America}

The functional distribution between the tenses of pretérito perfecto simple (PPS) and pretérito perfecto compuesto (PPC) is a topic that has been studied by several authors (Caravedo and Klee 2012; Escobar 1997; Hurtado 2009; Jara Yupanqui 2009; among others) From an aspectual point of view, the former is associated to the aorist (or perfective), while from a temporal perspective it represents a delimited event with a beginning and end located in a pre-hodiernal past that is sometimes marked by the presence of a temporal locator (TL) which disassociates the event from the present of the speaker (yesterday, two weeks ago, last month). The latter is associated with the perfect aspect and at a temporal level is bound to the moment of enunciation to express events that the speaker considers not accomplished or that have occurred in the immediate past or in the recent hodiernal past (Luisa ha llegado hace un rato) ${ }^{1}$ and is sometimes supported by temporary locators linked to the present (now, today, this week, this year, etc.).

Although the Nueva Gramática de la Lengua Española ('New Grammar of the Spanish Language' (NGLE)) (RAE and ASALE 2009, p. 1721) points out the difficulty of drawing a clear dividing line between the uses and values of the PPS and those of the PPC in Spanish due to the great dialectal variety that the two forms present in this language (especially the latter), it is possible to highlight that European Spanish, with the exception of Galicia and the Canary Islands, tends to develop the

1 The examples in Section 1 belong to the NGLE (2009), pp. 1721-1736. 
compound form to the detriment of the simple, while American Spanish is prone to the reverse phenomenon. In any case, several studies carried out in the Latin American framework have shown that the PPC is used more than what is believed in American Spanish.

The NGLE outlines the uses of the PPC and classifies them by dialectal areas. However, given that the pretérito perfecto compuesto is the verbal form that presents the greatest diatopic variety, its geographical distribution is very complex. The NGLE is very clear in terms of the dialectal values of the compound form in the Spanish spoken in Spain, but not to the same extent as regards the Spanish spoken in America. This could be due to the proposed distribution area being rather generic, and does not reflect all the dialectal nuances of the uses of the PPC.

Taking into account what is stated in the NGLE, only three of the described values are used in a generalized manner throughout Spanish-speaking geographical areas: the experiential value ( $\mathrm{Ha}$ viajado muchas veces a Europa), the resultative/evidential value or of verified facts (;Cómo han subido los precios!) and the one related to topical or recent news (Ha resultado herido). The remaining values are used in all dialectal areas, although with different interpretations, or are used exclusively in certain areas.

In addition to the three values mentioned above, the NGLE explains other values of the PPC, such as: continuous value, hodiernal or recent events, evidential narrative, non-resultative evidential, iterative and resultative values.

The PPC with continuous value is used in Spain and Latin America, but the interpretation of the extent of the aforementioned situation varies according to the geographical area in which the compound verbal form is used. Thus, in European Spanish (except in that spoken in the Canary Islands and in the Northwest of the Peninsula), in the Antilles, Andean (especially in Bolivia and Peru) and in the Northwest of Argentina, the sentences Sigo viviendo aqui or Ya no vivo aquí can be deduced from the sentence He vivido aquí treinta años. However, in the rest of the American areas, the interpretation of this sentence with the present perfect continuous tense (Sigo viviendo aqui) is almost forced.

In much of Spain, Peru, Bolivia, Paraguay, northwestern Argentina and part of Central America, the hodiernal PPC (for recent events) is used (limited to the current day: Luisa ha llegado hace un rato) and the extended pre-hodiernal PPC (for facts presented as current) is used without the presence of temporal locators (Luisa me ha regalado este vestido).

The PPC with narrative evidential value is used after the simple past or imperfect tense (Ayer fuimos a una fiesta. ;Cómo nos hemos reído!) in Central America (Nicaragua, Costa Rica and other Central American countries), Peru and several countries in the Caribbean area to bring the events closer to the perspective of the listener or the reader.

The PPC with non-resultative evidential value is used only in part of the Andean area (particularly in Ecuador) to highlight the novelty or surprise of what has just been revealed. It is not related to temporality, and is probably a linguistic calque of the Ecuadorian Quichua. Thus, the phrase Ha sido caro expresses surprise after having discovered the price of a product.

Past tenses either of the resultative and prospective type, or for planning, are also used when it is needed to emphatically express an action as accomplished, even though it has not been carried out yet (Mañana a estas horas, seguro que ya hemos terminado el informe). However, the PPS is preferred in Mexico, some Central American countries, Río de la Plata and Peru.

The PPC shares the usual or iterative interpretation value with the present tense and usually appears with universal quantifiers (cuando, cada vez, siempre, etc.; when, every time, always, etc.), but it is not specified in what geographical areas this use is common (Siempre que han podido nos han fastidiado).

\subsection{Innovative Values of the PPC}

The NGLE's description of the use of the PPC is very detailed, yet it does not reflect all the values that are peculiar to the different dialectal varieties. Reference is made to values and uses of the pretérito perfecto compuesto that are still not very well known, such as evidential, semantic-pragmatic, narrative 
and discursive values² ${ }^{2}$ as documented by Montero Cádiz (2015), Bustamante (1991), Pfänder and Palacios (2013), Escobar (1997), Palacios Alcaine (2007), Caravedo and Klee (2012), Jara Yupanqui (2009, 2011, 2013), Moreno Burgos (2015), De Jonge (1999), Rodríguez Louro (2009) and Rodrigues Parrihna (2014) in their studies. Specifically, in works by Caravedo and Klee (2012) and Jara Yupanqui (2011, 2013), the presence of the PPC in narrative clauses is highlighted more in Andean Spanish than in the Spanish of Lima to indicate emotional content, psychological relevance for the speaker, narrative climax, change of theme, specification, comment, reported speech, succession, outcome and summary. On the other hand, Escobar's work (Escobar 1997), also in the area of Peru, underlines the use of the PPC when the speaker wishes to emphasize their protagonism or direct involvement, as a witness or as an agent, in the events they narrate. As far as the area of Ecuador is concerned, however, Palacios Alcaine (2007) gives evidence of the opposite phenomenon-that the speaker selects the compound verbal form when they want to express their detachment from the message they are conveying because they did not personally experience what they expresses in their utterance and are either not sure what has happened, or do not trust the source of information.

In contrast to the general considerations discussed so far, two quite clear trends stand out that are probably due to the influence of contact with other languages. On the one hand, there is resistance to the grammaticalization of the PPC, even with the value of perfecto, for which canté is used indistinctly for both the aorist and the perfecto (Ayer/hoy canté). As indicated above, it is a secondary option in European Spanish, as its use has been located in Galicia, Asturias and the Canary Islands, while it is a primary option in American Spanish. There is another phenomenon that is the aoristicization of the PPC, or rather the use of he cantado in pre-hodiernal contexts that cannot be linked to the moment of speech (Ayer he ido al cine). Literature on the subject shows that there is a tendency towards the consolidation of periphrastic forms to the detriment of simple forms. As mentioned previously, this use exists in some areas of the Andean Spanish spoken on the Peruvian coast, in Argentina and in Bolivia, but is not recognized by the NGLE in European Spanish, although it has been registered in areas of peninsular Spanish and other areas of Latin America.

\subsection{PPC with Aoristic Value}

The NGLE also recognizes the use of the perfective or aoristic PPC in Bolivia, on the Peruvian coast, in Paraguay and in the northwest of Argentina, with temporal expressions peculiar to the past tense (Luisa ha llegado a esta ciudad hace tres años), but no mention is made of its use in other areas of Latin America or in European Spanish. This has been documented in studies by De Mello (1994), Serrano (1994) and Bermejo Calleja (2017) in Madrid, Kempas $(2008,2014)$ in several areas of Spain, Burgo (2008) in the Basque Country, Azpiazu (2012, 2014, 2015) in Salamanca and San Sebastián and Montoro del Arco (2017) in Granada.

The use of pretérito perfecto compuesto (he cantado) in pre-hodiernal contexts, or rather, when the verb designates perfective events (events that occurred a day before the enunciation), occurs in contexts in which the simple verbal form should appear (canté) according to the standard rule. However, if the verb is located in a wide temporal space that in some way includes the enunciation moment (EM), the phenomenon does not cause any perplexity given that, as reported above, such use is considered by the NGLE to be an 'extended present' value normally used in Spain. Nevertheless, as Azpiazu (2012) points out, it is strange when the PPC is used together with temporal locators (TL) that clearly separate the expressed event from the moment of enunciation, or when it is used in narrative contexts located in a past detached from the present. Therefore, Azpiazu (2012) underlines that the sentence Ayer he visto a Pedro paseando con su perro would be considered an incorrect or ungrammatical sequence from the theoretical-descriptive perspective of the standard language. This phenomenon, called 'aoristic drift' (Squartini and Bertinetto 2000), deriva aorística (Azpiazu 2014) or aoristización (Kempas 2008; Azpiazu

2 About the use of the PPC by Latin American speakers in migration contexts see Ariolfo (2018). 
2014), initially arises in colloquial speech and consists of the semantic evolution of aspectual original values of the perfect of the PPC towards aoristic values, typical of pretérito perfecto simple. In Section 1 , it was highlight that the NGLE records the extension of the value of the PPC with aoristic aspect on the Peruvian coast, in Bolivia, in Paraguay and in the northwest of Argentina. As for European Spanish, many of the authors who have studied the subject, both in Spanish and in other languages, point out the functional grammaticalization where the compound form gains values that are typical of the pretérito perfecto simple. However, the author prefers to be more cautious about the phenomenon in the Peninsula because, in her opinion, it deals with

un sistema no asentado, donde el uso real de la lengua no coincide con el estándar representado en la escritura, a lo cual debe añadirse una gran dispersión dialectal, de la que apenas tenemos un conocimiento ordenado. (Azpiazu 2012, p. 333) ('an unsettled system, where the actual use of the language does not coincide with the standard represented in the writing system, characterized as well by a large dialectal dispersion of which we barely have a systematic knowledge.')

Hence, this use of the PPC has been documented and analyzed in Europe by De Mello (1994), Serrano (1994) and Bermejo Calleja (2017) in Madrid, by Kempas (2008) in several areas of Spain, by Burgo (2008) in the Basque Country, by Azpiazu $(2012,2014$, 2015) in Salamanca and San Sebastián and by Montoro del Arco (2017) in Granada. In the Latin American scenario, the phenomenon has been studied by Soto (2014) in nine American capitals, Mexico City, San Juan in Puerto Rico, San José in Costa Rica, Caracas, Bogotá, Lima, La Paz, Buenos Aires and Santiago in Chile in contrast to the use of the PPC in Madrid. His study gives rise to interesting considerations. On the one hand, the greatest occurrence of aorist usage occurs in areas where the PPC is more commonly used. On the other hand, the aorist is related to the relevance that the narrated facts have for the speaker, and this expresses the importance of subjectivization. There are three situations regarding the aoristicization of the PPC defined by Soto: in most American capitals, use is made of the resultative, existential or continuative PPC, although possibly with an associated subjective valuation; in Madrid, where hodiernals and sporadic aorist forms exist together with the cases of perfect; and in La Paz and Lima, where aorist values of relevance occur in addition to perfect tenses.

According to Soto (2014), there is a close relationship between PPC frequency, progress in aoristic drift and subjectivization. Although it is not possible to establish a strict causal relationship between these phenomena, it can be assumed that the aoristic drift may be the consequence of a process of gradual subjectivization of the PPC; objective restrictions are eliminated and the speaker's subjectivity prevails, so not only do they relate facts, but they also evaluate the relevance of those facts at the moment of speech.

On the other hand, Bermejo Calleja (2017) states that the use of the aoristic PPC is related to the speaker's strategies. Therefore, in his narrations a fragment of the narrated event is brought closer to the enunciation situation, achieving an expressive, discursive type of effect and sometimes coloring the story with emotional and affective values. In this sense, the use of the aoristic PPC would be a strategy employed in direct speech (Ariolfo 2018) that includes the participation of the speaker and involves the interlocutor.

It is well known that the use of the PPS and the PPC varies greatly throughout Italy, with a marked contrast between the North and the South, as highlighted by Bertinetto and Squartini in 1996. The north of Italy is characterized by a clear, if not exclusive, predominance of the PPC, while, on the contrary, the PPS prevails in the South of Italy, and in Central Italy both forms seem to be more appropriately used or at least more balanced. In addition, Bertinetto and Squartini state that the contrast between the different varieties of Italian is clearly perceptible in the spoken language, but not necessarily reflected in the written, which is influenced by the literary model. Furthermore, the compound form is in continuous expansion, especially in the central and southern areas (Bertinetto and Squartini 1996, pp. 383-84). In another publication, the authors point out that the Italian present perfect can be used to refer to past pre-hodiernal and completely concluded events as well as to narrate past personal 
experiences both in an oral and informal way. As was said before, this use varies according to the regions and speakers; however, we emphasize that it is much more widespread in the north of the country (Squartini and Bertinetto 2000).

\section{Objectives, Corpus and Methodology}

The purpose of this paper is to detect and analyze the appearance of the PPC with aoristic value in the spontaneous speech of a group of high school students from Peru and Ecuador, taking into account the different varieties of American Spanish in the Genoese area. Based on a corpus of 16 semi-guided interviews given to Latin American students living in Genoa, in this research we aim to shed light on the factors that can lead speakers to the use of the PPC with aoristic value. To this end, due consideration is given to the characteristics of this verbal form, the syntactic environment in which it is used, combinations with other verbal forms, adverbial complements, temporal expressions and deixis, as well as the communicative context in which the narrated facts are inserted.

We hypothesize that the aoristic use of the PPC in the Genoese context is due to subjective or pragmatic topics, and therefore bound to the context and intentions of the speaker, to his/her attitude towards the narrated facts and to the situation in which they occurred, as well as the result of a prolonged duration of contact with the northern Italian language.

Table 1 sums up the main characteristics of each interviewee and the number of occurrences of the compound PP found out in their speech.

Table 1. Characteristics of the interviewees and number of occurrences in the PPC. ${ }^{3}$

\begin{tabular}{cccc}
\hline Country of Origin & Migration Age & Years of Residence Italy & PPC \\
\hline Ecuador, Guayaquil & 5 & 13 & 3 \\
Ecuador, Manabí & 16 & 2 & 3 \\
Peru, Lima & 6 & 12 & 23 \\
Ecuador, Guayaquil & 7 & 9 & 30 \\
Peru, Lima & 2 & 13 & 36 \\
Ecuador, Guayaquil & 11 & 7 & 23 \\
Ecuador, Manta & 13 & 5 & 28 \\
Ecuador, Manta & 9 & 5 & 13 \\
Ecuador, Portoviejo & 10 & 8 & 7 \\
Ecuador, Sucumbios & 12 & 6 & 21 \\
Ecuador, Quito & 7 & 13 & 21 \\
Peru, Lima & 8 & 12 & 10 \\
Ecuador, Guayaquil & 16 & 4 & 12 \\
Ecuador, Guayaquil & 16 & 4 & 15 \\
Ecuador, Quito & 11 & 8 & 20 \\
Peru, Lima & 16 & 2 & 101 \\
\hline
\end{tabular}

The interviews had an average duration of one hour, consisting of several parts and concerning personal issues and events that occurred in the life of the interviewees; as a rule, they focused on general topics. Most interviewees provided stories that referred to their lifetimes spanning migration, school life, trips and family life. They used anecdotes of all kinds, as well as dreams and memories. Some responses were structured more in the form of a dialogue, while others were more narrative. The majority of the topics revolved around past events, generating stories of spontaneous orality in which the temporal element was of the utmost importance (Caravedo and Klee 2012). We chose to rely solely on semi-directed interviews, because this method is more natural than other data collection methods, such as the evocation test used by Kempas (2006). The test of evocation consists of a survey in

3 All subjects gave their informed consent for inclusion before they participated in the study. The study was conducted in accordance with the Declaration of Helsinki, and the protocol was approved by DISPO-UNIGE (Project FRA 2016). 
which the informants are provided with certain sentences in which the verb is missing and they must decide which verb to choose and what verbal form to use, relying exclusively on the linguistic context. Basically, these were gapped sentences with adverbial complements that served to locate an event at a certain point in the past that was clearly disconnected from the present-that is, in pre- hodiernal contexts: yesterday, two days ago, last week, at the end of July, and so on, either with hodiernal complements or without them. Although this method can be easier to prepare, since variables can be allegedly kept more under control thanks to the homogeneity of the materials provided to carry out the analysis, this is a test in which the sentences are totally decontextualized, regardless of the actual pragmatic conditions that usually influence choice of verbal form when a speaker structures their speech. When interviewed, the participant is not forced to adapt their verbal form to a speech alien to them. On the contrary, the verbal form becomes the core of the discourse, a nucleus around which the rest of the text is configured. Thus, the information offered by the interview-based corpus shows the real functioning of the language, although it may be scattered and scarce, and this makes it more valuable than the evocation test. On the other hand, in the evocation test the informant is more aware of the academic and formal nature of the test, which can influence their responses by eliminating spontaneity. So when facing a test with these characteristics, they could feel inhibited by the possibility of making mistakes, which would totally degenerate the aim of the test itself.

Such restraint could be even more justified, or understood, if we consider that many of the Latin Americans born in Italy, or who arrived in Italy at preschool age or had very few years of formal education in their countries of origin, do not have a good knowledge of written Spanish. They do not even have a lot of knowledge of grammar and mainly use oral Spanish. In a similar context, bilingualism is often still considered a source of confusion by many teachers who regard it as a sort of suspicious bilingualism (Lorenzo and Vez 2011, pp. 26-27) that is hardly prestigious, and unfortunately puts migrant children and young people at a disadvantage as it is inevitably associated with migration and poverty (Ariolfo 2012, 2014; Ariolfo and Viterbori 2016) and the outcome of the circumstances of life instead of free choice. These perceptions, combined with a lack of adequate tools and strategies to accompany these types of students in their language learning path, have contributed to confounding a part of the teaching staff who continue to advise against the use of the Spanish language even at home, convinced there is a negative correlation between language of origin and difficulties at school.

In the following pages we will outline the corpus and comment on a few fragments from the interviews conducted with respondents belonging to Latin American immigrant communities that use the PPC with aoristic value.

Hence, the aim is to qualitatively scrutinize the cases in which the phenomenon under analysis appears in our corpus, and not to highlight its mainstream uses. This is because such an approach would not be possible, due to the scarce availability of data we can rely on.

We are aware that any possible assumptions that may arise from the analysis of the individual cases should be confirmed by a vast empirical support in future research.

\section{Analysis of the Interviews}

First of all, it is necessary to underline that in this research we will concentrate on the use of the compound form even though the simple verbal form prevails, since the use of the PPS predominates in the discourse of all the respondents. Reference will only be made to the simple form when we consider it useful for the purposes of our study. In the present study, a total of 207 occurrences of the PPC have been extracted, some of which correspond to the canonical uses described in the NGLE while, in contrast, others correspond to innovative uses. Many of the different uses have already been registered in other contexts in several investigations, such as Pfänder and Palacios (2013), Palacios Alcaine (2005, 2006, 2007), Bustamante (1991), Henderson (2006), Caravedo and Klee (2012), Jara Yupanqui (2009), de Araujo (2014), among others. However, in this paper, special attention will be paid to the forms of the PPC with aoristic value that appear in our corpus. 
In Example (1), the interviewee is an 18-year-old girl who had arrived in Genoa from Guayaquil during childhood. She uses the PPC while referring to her mother's partner who died the previous year, even though the preferred verbal form should be the simple one. According to the criteria that Azpiazu (2014) and Bermejo Calleja (2017) have established in order to recognize if the PPC has aoristic value, the verbal form in question is used in a narrative sequence with no experiential value and is preceded by a temporal delimitation, el año pasado ('last year'):

(1) De parte de mami no tengo hermanos, de parte de papá, pienso que sí ... O sea, mi papá se separó de mi mamá cuando yo ya estaba en la panza, me parece ... yo no lo conozco ... Sinceramente, no sé cómo fue, es que me da cosa preguntarle y hacerla sufrir. Ella se volvió a casar con otro señor, pero hace ... el año pasado se ha muerto ... Si, tenían juntos ... diez años ... Yo no me llevaba bien. Al inicio sí, cuando era chiquita sí, pero ya después, ya no me llevé porque ... digamos que la apartaba a mi mami de la familia. Entonces a mí eso no me gustaba. Porque la apartaba a ella y me apartaba a mí. $Y$ yo soy bastante unida con mi familia, entonces no me gustó. (Guayaquil, five years old when she arrived in Italy, 13 years in Italy.) $)^{4}$

It should be noted that the interviewee uses the simple form for her narrative sequence, but there was a kind of interruption in her story when she introduced the death of her mother's partner, to whom the interviewee did not feel very close. However, she probably recognized the pain that this event implied for her mother, or was expressing surprise, as her mother's partner was quite young when he died. In this way, the use of the PPC brings the story closer to the present and makes the speaker participate in some way in the narrated fact.

In Example (2), the speaker himself is involved in the narration of a pre-hodiernal event next to a temporal adverb which did not designate an interval but included the present. It is clear that context is also fundamental, because if there are other verbs then the tense they are conjugated in is important; the closer they are to the present, the more they tend to suggest the use of the PPC. In this case, we have two conjugated verbs in compound forms, but rather than the former influencing the latter there is rather a unique event of vital importance to the interviewee. He is the protagonist of what he narrates, and the agent of facts that radically changed his life: the move to Italy, a different school and the creation of new friendships during a stage in his life when everything was different:

(2) Yo he venido a Italia con trece años, aquí cumplí los catorce. Porque vine el veinte, vine el veinte de febrero, el 20 de febrero he llegado aquí, entonces yo tenía 13 años, y acá en julio cumplí ya los 14. Y para otra etapa (... ) otro colegio, todo diferente ... Pero igual las amistades siempre quedan, me gusta eso, desde que vine, ya son tres veces que voy de vacaciones a Ecuador. (Manta, 13 years old when he arrived in Italy, five years in Italy. $)^{5}$

The interviewee uses the compound form on two occasions, even referring to an event punctually located in the past thanks to the explicitation of the temporal marker con 13 años and el 20 de febrero. This event occurred six years ago, so it is concluded and temporarily distant with respect to the moment of enunciation (entonces yo tenía 13 años), but still very close emotionally to the speaker. The use of the simple form, repeated twice in a row (vine el 20, vine el 20 de febrero), should also be noted as a resource to give the story emphasis. In this selection, pragmatic variables have great influence: the interviewee

4 I do not have any siblings on my mom's side. I think I have some on my dad's side. I mean, my dad got separated from my mom when I was still in her belly, I think ... I do not know him ... Honestly, I do not know how it was. The fact is that I don't dare to ask and it pains me to make her suffer. She got married for the second time to another gentleman, but ... last year he has died ... Yes, they lived together ... 10 years ... I did not get along with him. I did at the beginning when I was little, yes, but later, I did not get along with him. Let's say he took my mom away from our family. So I did not like that. Because he took her away and he took me away from her. And I am quite close to my family, so I did not like it. (our translation).

5 When I have arrived in Italy I was 13, and I turned 14 here in July. As I arrived on the 20th, on February 20th I have arrived here, so I was 13, and I turned fourteen here in July. And then another step (... ) a new school, everything different ... But anyway, friends are here to stay, since I have come here, I have been to Ecuador three times on holiday. (our translation). 
wants to bring the facts closer to the perspective of his interlocutor by making him a participant in his experience.

In Example (3), the interviewee remembers intense emotions evoked by his return to Lima in the company of his mother after 10 years of absence. The reunion with the whole family in his birthplace is a very strong experience, which the interviewee transmits through verbal selection and his words: casi se pone a llorar, feliz de la vida, abrazando a todos, tenían lágrimas en los ojos. Indeed, next to the temporal locator ese dia, although we expect the simple verbal form due to the fact that it is placed before the compound verbal form, the speaker chooses two verbal forms in the PPC, hemos viajado and hemos regresado. These are accompanied in both cases by the adjective juntos, which express his intention to bring the narrated event closer to the present and emotionally highlight how important it was not to leave his mother either going to or coming from Peru:

(3) Me recuerdo que mi mamá casi se pone a llorar, feliz de la vida, después de 10 años, porque ese día, ella regresaba junto conmigo, ese día hemos viajado juntos y hemos regresado juntos. Y ... nada ... mi mamá estaba emocionada de ver de nuevo a toda la familia. Estaba abrazando a todos lo más que podía. Y también mi papá, igual, porque estaba ... nos esperaba en el aeropuerto, nos esperaba la familia de mi mamá, sus primos, sus tíos, la familia de mi papá, la mamá de mi papá, sus hermanas, sus hermanos. Y los dos se quedaron un poquito, ... o sea felices, ... tenían lágrimas en los ojos, pero estaban contentos. Esa vez nos quedamos un mes ... poquito, pero me gustó tanto ... porque estuve en la casa donde nací porque, yo nací, prácticamente me crie en la casa, o sea que vivía con mi abuelita y mi mamá y mis hermanos, porque mi papá ya había viajado acá. (Lima, six years old when he arrived in Italy, 12 years in Italy.) ${ }^{6}$

In Example (4), the interviewee narrates a significant personal fact: her father's despair when, on finding himself unable to manage his daughter's behavior, he feels helpless and cries, showing his weakness in a situation that is getting out of hand. The compound form se ha puesto a llorar, inserted in a narrative context preceded by the temporal marker en ese momento makes us think again of subjective aoristicization that shows how shocking it was for the daughter to discover that her father would cry for a reason attributable to her. It is very likely that this option is used as a means of highlighting the surprise of the speaker in front of the situation being described.

As said earlier, the linguistic context is also important, because there are other verbs conjugated in tenses closer to the present that are inserted into direct speech and which precede and follow the verbal phrase in the PPC to fully update the story of the interviewee in a natural way:

(4) No, porque ahorita ya he cambiado, ya ... Yo me iba ... Por ejemplo, hubo esa ocasión que justo mi mami se fue ... El tercer día mi novio, ... yo hice una cosa a mi novio, y mi novio me dijo: mira, terminamos aquí. Y yo le dije: ok ... Y ahí él se metió con mi mejor amiga ... Decía que mi santo remedio para mí era irme a las discotecas, irme a tomar, irme a fiestas. Pero no paraba. Me fugué una semana del colegio. Mi papá vino acá a hablar y le dijo: Señora, ¿cómo está mi hija?, pero no le diga que yo vine ... (y la profesora) Si su hija desde una semana que no viene ... En ese momento mi papá se ha puesto a llorar y todo. Y después del llanto, ... creo que ... no me importa si mi papá llora, ... continuo a hacer lo mismo, y hacía lo mismo .... (Quito, seven years old when he arrived in Italy, 13 years in Italy. $)^{7}$

6 I remember when my mom almost started crying, she was very happy, after 10 years, because that day, she was returning with me, that day we have travelled together and we have come back together. And ... nothing ... my mom was excited to see the whole family again. She was hugging everyone as much as she could. And my dad, too, because he was ... he was waiting for us at the airport. My mom's family, her cousins, her uncles, my dad's family, my dad's mom, his sisters and his brothers were waiting for us. And they stared at each other for a while ... happy ... they had tears in their eyes, but they were happy. That time we stayed a month ... a short time, but I liked it so much ... because I was in the house where I was born, in the house where I grew up, where I lived with my grandma and my mom and my brothers, because my dad had already come here. (our translation).

7 No, because right now I have changed, already ... I was leaving ... For instance, just by coincidence my mom left ... The third day my boyfriend ... I did one thing to my boyfriend, and my boyfriend said "Look, we ended up here" and I said "ok 
In Example (5), the interviewee uses the compound verbal form ha divorciado followed by a temporal marker that locates the action in a punctual and concluded past moment ( 5 años atrás 'five years ago'), so we expect the simple verbal form. It is noteworthy that in the verbal context in which the form $h a$ divorciado is expressed there are other verbal forms close to the present, and it is possible that they tend to suggest the use of the PPC to the interviewee:

(5) Sí... yo he vivido en la casa de mi abuelita siempre por parte de mi papa ... siempre, pero mi mamá, o sea, viviamos ahí nosotras dos, porque mi mamá comunque tenía una buena relación con mi abuela ¿no?, con la familia de parte de mi papá, pero mi mamá ha divorciado de mi papá hace como 5 años atrás ... 6 años atrás ¿no? O sea, no eran legalmente divorciados porque los papeles recién ahorita han salido, el divorcio ... . (Lima, 2 years old when she arrived in Italy, 13 years in Italy. $)^{8}$

However, the best hypothesis is that perhaps aoristicization occurs by assimilation to Italian. As pointed out in a previous study (Ariolfo 2018) the aoristicization of the PPC may be affected by an external factor in the Genoese migratory context (i.e., the period of residence in Genoa and the prolonged contact with the northern variety of Italian). It is known that the distinction between the PPC and the PPS is in clear regression in northern Italian in favor of the compound form, which suggests that the distinctive features of the PPS do not seem to be necessary for northern Italians. Indeed, in Genoa, the present perfect is used on contexts in which speakers from other areas of Italy use the simple past. In this regard, Squartini and Bertinetto (2000) point out that reference can be made to past pre-hodiernal and completely concluded events when the Italian PPC is used. In addition, it is usually used orally and informally to narrate past personal experiences. This use varies according to the region and the speakers, although it is most widespread in the north of the country. Therefore, it is possible that the interviewee who, after 13 years of residence in Italy (having emigrated at the age of two), and having been completely schooled there, used the PPC with an aoristic, aspectual value in a pre-hodiernal context due to a linguistic convergence between the two typologically close languages as a result of prolonged contact with the Italian spoken in Genoa. In this case, perhaps we might be facing an incipient phenomenon - the formation of a derivative, migratory, emergent or 'diasporic' verbal variety.

Another factor of no less importance that could support our hypothesis is the fact that the verb divorciarse, referring to a person (as in the case of the example), should be used in its pronominal form, that is, se ha divorciado. However, the interviewee uses a non-pronominal form ha divorciado, which suggests that she could have borrowed it from Italian that prefers the non-pronominal form with the auxiliary haber: mia mamma ha divorziato. On the other hand, the influence of Italian is proven by the presence of the form eran divorciados instead of estaban divorciados where the adjective divorziato is preceded by the verb ser (essere divorziato/a) and not estar, as in Spanish (estar divorciado/a).

Finally, Example (6) is a brief narration of a very unpleasant fact: a robbery at school. In the linguistic context, there is only one temporal locator, un dia, but we know that it is an episode that occurred in the previous schooling experience of the protagonist, who at the time of the interview was in the fourth year of secondary school; hence, we are facing a finished fact with no connection to the present. The story mainly highlights the use of two tenses: the imperfect to describe the context of the narrated event, and the PPC to sequence the order of the events (which is usually expressed by the PPS in a narration) and mark the emotional intensity with which the young woman lived that episode.

\footnotetext{
.." And he got involved with my best friend ... He said that the easiest way for me to get the problem solved was going to clubs, drinking, and going to parties. But this was not enough. I ran away from school one week. My dad came here to talk with my teacher and said, "Madam, how's my daughter doing? but do not tell her that I came ... " "Your daughter has not been coming for a week..." At that moment my dad has started crying. And after crying ... I believe ... "I do not care if my dad cries ... I continue to do the same," and did the same ... (our translation).

8 Yes ... I have lived in my grandma's house, always on my dad's side ... always, but my mom, that is, we lived there, both of us, because my mom comunque had a good relationship with my grandmother from my dad's side, right? but my mom and my dad has divorced about five years ago ... six years ago, right? That is, they were not legally divorced because the papers have come out just now, the divorce... (our translation).
} 
It is also interesting to note that the verbal sequences in the PPC lack a defined agent. As a matter of fact, verbs are either preceded by the indefinite pronoun alguien (alguien ha entrado, ha abierto ... y se ha llevado) or by implied subjects in indefinite plural form (han entrado y han abierto):

(6) Recuerdo un día que estábamos en el gimnasio de la escuela y ahí donde estaban los baños, al lado, había una puerta de esas grandes, pesadas y unos bancos donde poníamos los bolsos. Ahí dejábamos todo. Entonces, mientras nosotros estábamos haciendo los ejercicios, alguien ha entrado, ha abierto la puerta y se ha llevado algunos bolsos ;con los celulares, el dinero, todo! Ha sido horrible porque han entrado y han abierto la puerta, jen nuestra escuela! Nosotros pasábamos horas y horas ahí ... (Quito, seven years when she arrived in Italy, 13 years in Italy.) $)^{9}$

It should be noted that in the examples commented upon, the verb forms in the PPC in bold type always appeared in relation to events that had great emotional impact, such as some culminating moments in the migratory history of the speakers (expressed by the verbs venir, llegar, viajar and regresar), weeping, death or separation from a person dear to the interviewee, or even the story of a robbery.

\section{Conclusions and Perspectives}

Given the scarcity of the available data-cases of the PPC in the pre-hodiernal context are very few in our corpus - and the fact that the majority of cases of the aoristic PPC were found only in five of the 16 interviewees, we view these results with caution and express the prudence towards any generalized explanation or final conclusion drawn.

Through the analysis of some fragments of the interviews, we have ascertained that the PPC is used by native Latin American speakers even in contexts in which the PPS would be used in the Iberian variation or in other American variations.

Although the nature and reduced extension of the corpus forced us a priori to discard socio-cultural clashes, as well as the influence of the variables of gender and age, as possible factors that could result in the use of the PPC in the narrative sequences in pre-hodiernal contexts, the research suggests the possibility that the use of the PPC in oral discourse may be related to internal and external factors which have arisen in the migratory context, as stated in a previous study (Ariolfo 2018). In other words, it could result from the speaker's desire or need for integration, or the effect of prolonged linguistic contact and formal learning of the local language (i.e., Italian). As we pointed out in Example (5), the fact of having completed primary and secondary studies in Italy and having been in prolonged contact with the characteristics of northern Italian could have in some way led to the aoristicization of the PPC. At the same time, we are aware that to better test our hypothesis, more empirical support should be provided through forthcoming research.

The fact that there were few speakers in the sample who used the aoristic PPC makes us think that the process of aoristicization was far from systematic in the speech of the interviewed students, and was probably linked to their ideolect. We agree with Azpiazu (2015) that the phenomenon is pragmatic rather than grammatical. It is typical of orality and contextually conditioning: the speaker chooses the verb form according to the context, possibly motivated by the wish to make their narration more current and, therefore, interesting for the interlocutor. Ultimately, we are facing a narrative technique that aims at updating the narrated events and bringing them closer or of greater similarity to the phenomenon, which occurs when using the conversational historical present tense or direct speech, as we highlighted in a previous study (Ariolfo 2018). Undoubtedly, the study of the pre-hodiernal PPC should be associated with these resources. Indeed, when the speaker narrates an event that is not temporally linked in any way to the present as if it were so, their goal is not to create new grammatical

9 I remember one day we were in the school sports hall, just inside the toilets, next to the toilets door, there was a big, heavy door and some benches where we put the bags. There we left everything. So while we were doing the exercises, someone has come in, has opened the door and has taken some bags with cell phones, money, everything! It has been horrible because they have entered and have opened the door, in our school! We spent hours and hours there ... (our translation). 
structures, but to draw the interlocutor's attention, express themselves effectively and bring the narration closer to the elocutionary moment by invigorating it and presenting it in a more vivid and expressive way. For this reason, as suggested by Azpiazu (2015), the study of the aoristicization of the PPC in Spanish must necessarily pass through a detailed analysis of the discursive and stylistic conditions of each of its occurrences.

As commented in the previous section, the analysis of the data shows that the phenomenon of aoristicization of the PPC is still not very stable, and that it is closely linked to stylistic preferences of speakers. It is also linked to the expressive values that it holds for the speaker's vision who selects one or another verbal form to structure the discourse (i.e., the circumstances that influence each form, as well as the semantic or pragmatic values that are hidden behind them). Indeed, what is actually recurrent in all the examples of our corpus is that the speaker tries to bring cases of their own or their relatives' experiences closer to the present. By doing this, they want to update and make a past experience they have directly witnessed, or that has been lived by a relative or a person close to them, more credible for the interlocutor. The compound form is then also narrative, and is used to relate events about which the speaker can in some way witness.

We agree with Soto (2014) that the decrease in restrictions on the use of the PPC seems to be associated with an increase in subjectivity. Although there are few samples of uses of the PPC with aoristic value to analyze, they all highlight situations that are meaningful to the speaker, who is not only talking about their life, but is sharing their point of view on the relevance that such episodes have at the moment of the narration.

Regarding extralinguistic context in cases of the PPC with aoristic value that appear in our corpus, we spotted the presence of a pre-hodiernal or past context with temporal locators that mostly precede the compound verbal form (except for Example (5), in which the temporal locator is located after the verbal form in the PPC) expressed in the first singular and plural person, and that refers to an event in which the speaker took part as the protagonist. The speaker presents themselves as the main source of the information provided and the guarantor of its truthfulness at the same time. Therefore, the occurrence of the first person in these instances may be an indication of a use that can be considered epistemic and evidential. In our corpus, there are also three cases of the aoristic PPC in the third singular person that refer to events that vitally affected the speaker, because it narrates events that they know well because they are emotionally close to the person affected by the incident. There is a single PPC example of aorist in the third plural person, whose agent is undefined and generic, whether expressed in singular or plural form.

As we previously pointed out, it is not possible to speak of functional grammaticalization of the PPC, since it is a very difficult phenomenon to cover in all its dialectal and diaphasic complexity and of which we still have an insufficient homogeneous vision, in spite of the numerous studies carried out. This is especially due to the absence of uniformity in data collection methods, which can lead to erroneous or hasty conclusions. Although the evocation test would allow easy control of some variables, it is a test in which to a certain extent the informant is obliged to explain their internal knowledge of the language, which they probably lack, as was the case with our interviewees. On the other hand, it is a decontextualized language test and, as we have seen, the PPC with aoristic value appears in real speech in very concrete and personal pragmatic conditions that are difficult to reproduce and systematize in an artificially created test. Since it is still a stylistic phenomenon that is more typical of the idiolect of some speakers than of others, studying it is very difficult. The aoristic drift of the PPC is still quite unsystematic and incipient, which makes it difficult to give a valid explanation for all cases without linking it to the specific context of each act of speech. Therefore, what has been reported up to now leads us to believe that the conclusions reached so far should be corroborated in future research, and we hope that this will be the case.

Funding: This research received no external funding.

Conflicts of Interest: The author declares no conflict of interest. 


\section{References}

Ariolfo, Rosana. 2012. Actitudes lingüísticas, inmigración y escuela. Un aporte para la reflexión y la práctica educativa. Lecce: Libellula.

Ariolfo, Rosana. 2014. Dalla parte degli insegnanti: Spunti per una riflessione sull'educazione plurale e multilingue. In Migrazione latinoamericana e discorsi istituzionali. Edited by Laura Mariottini and Alessandro Oricchio. Special Issue, Rivista RTSA-Rivista Trimestrale di Scienza dell'Amministrazione. vol. 2, pp. 40-53. [CrossRef]

Ariolfo, Rosana. 2018. El español de América en el paisaje lingüístico genovés. El pretérito perfecto compuesto en las narraciones de estudiantes latinoamericanos. In Paisajes lingüísticos de la migración. Contextos mediáticos, urbanos y formativos. Edited by Rosana Ariolfo and Laura Mariottini. Special Issue, Lingue e Linguaggi. vol. 25, pp. 323-45. Available online: http://siba-ese.unisalento.it/index.php/linguelinguaggi/article/view/18956/ 16217 (accessed on 15 December 2018).

Ariolfo, Rosana, and Paola Viterbori. 2016. Bilingüismo e inmigración: Actitudes lingüísticas y dificultades de aprendizaje en alumnos hispanohablantes. In Migraciones hispánicas: Discurso, sociedad y cognición. Edited by Rocío Caravedo and Francisco Moreno Fernández. Special Issue, Revista Cuadernos AISPI. vol. 8, pp. 51-73.

Azpiazu, Susana. 2012. El pretérito perfecto en el habla de Salamanca. Problemas metodológicos de las clasificaciones a la luz de una Lingüística de la Facticidad. RSEL 42: 5-33.

Azpiazu, Susana. 2014. Del pretérito perfecto al aoristo en el antepresente peninsular: Un fenómeno discursivo Formas simples y compuestas del pasado en español. Edited by Susana Azpiazu. Lugo: Axac, pp. 17-30.

Azpiazu, Susana. 2015. La variación Antepresente/Pretérito en dos áreas del español peninsular. Verba 42: 269-92. [CrossRef]

Bermejo Calleja, Felisa. 2017. Pretérito perfecto compuesto (PPC) en un corpus oral del español peninsular: Monólogos y conversaciones. In Pretérito perfecto simple y pretérito perfecto compuesto en español: Uso y gramatización. Edited by Susana Azpiazu and Carmen Quijada Van den Berghe. Special Issue, Orillas. vol. 6, pp.405-26. Available online: http://orillas.cab.unipd.it/orillas/06_02bermejo_astilleros/ (accessed on 15 December 2018).

Bertinetto, Pier Marco, and Mario Squartini. 1996. La distribuzione del Perfetto Semplice e del Perfetto Composto nelle diverse varietà di italiano. Romance Philology XLIX 4: 384-419.

Burgo, Clara. 2008. Tense and Aspect Grammaticalization in Bilbao Spanish. Chicago: University of Illinois at Chicago.

Bustamante, Isabel. 1991. El presente perfecto o pretérito perfecto compuesto en el español quiteño. LEXIS XV: 195-231.

Caravedo, Rocío, and Carol Klee. 2012. Migración y contacto en Lima: El pretérito perfecto en las cláusulas narrativas. Lengua y Migración 4: 5-24.

de Araujo, Leandro Silveira. 2014. A variação linguística no uso do pretérito perfecto compuesto espanhol: Ponderações sobre o estado da arte. Entretextos 14: 258-82.

De Jonge, Bob. 1999. El tiempo de todos los tiempos: El uso del presente perfecto en el español bonaerense. In Actas del XI Congreso Internacional de ALFAL. Las Palmas de Gran Canaria: Universidad de Las Palmas de Gran Canaria, pp. 297-304.

De Mello, George. 1994. Pretérito compuesto para indicar acción con límite en el pasado: Ayer he visto a Juan. Boletín de la Real Academia Española 74: 611-33.

Escobar, Ana María. 1997. Contrastive and Innovative Uses of the Present Perfect and the Preterite in Spanish in Contact with Quechua. Hispania 80: 859-70. [CrossRef]

Henderson, Carlos. 2006. Aspectos semánticos pragmáticos y discursivos del Pretérito Perfecto Compuesto. Available online: http://www.diva-portal.org/smash/get/diva2:283008/FULLTEXT01.pdf (accessed on 12 January 2019).

Hurtado, Silvia. 2009. El perfecto simple y el perfecto compuesto en Hispanoamérica: La inclusión o la exclusión del ahora de la enunciación. Estudios Filológicos 44: 93-106.

Jara Yupanqui, Margarita. 2009. El pretérito perfecto simple y el pretérito perfecto compuesto en las variedades del español peninsular y americano. Signo \& Seña 20: 253-81.

Jara Yupanqui, Margarita. 2011. Funciones discursivas y gramaticalización del pretérito perfecto compuesto en el español de Lima. Spanish in Context 8: 95-118. [CrossRef] 
Jara Yupanqui, Margarita. 2013. El perfecto en el español de Lima. Variación y cambio en situación de contacto lingüístico. Lima: Pontificia Universidad Católica del Perú.

Kempas, Ilpo. 2006. Estudio sobre el uso del pretérito perfecto prehodiernal en el español peninsular y en comparación con la variedad del español argentino hablada en Santiago del Estero. Ph.D. thesis, University of Helsinki, Helsinki, Finland. Available online: http://ethesis.helsinki.fi/julkaisut/hum/romaa/vk/kempas/ estudios.pdf (accessed on 3 January 2019).

Kempas, Ilpo. 2008. El pretérito perfecto compuesto y los pasados prehodiernales. In Tiempos compuestos y formas verbales complejas. Edited by Ángeles Carrasco Gutiérrez. Madrid: Iberoamericana, Frankfurt: Vervuert, pp. 231-73.

Kempas, Ilpo. 2014. Aportes empíricos a los estudios sobre el pretérito perfecto compuesto "aoristizado". In Formas simples y compuestas de pasado en el verbo español. Edited by Susana Azpiazu. Lugo: Axac, pp. 81-102.

Lorenzo, Fernando Trujillo, and José Manuel Vez. 2011. Educación bilingüe. Integración de contenidos y segundas lenguas. Madrid: Síntesis, pp. 26-27.

Montero Cádiz, Manuel Menardo. 2015. Acercamiento al empleo del pretérito perfecto compuesto del modo indicativo en la variedad cubana del español. Revista Nebrija de Lingüística Aplicada a la Enseñanza de Lenguas 18: 25-40. Available online: http://www.nebrija.com/revista-linguistica/numero-18-2015 (accessed on 3 January 2018).

Montoro del Arco, Esteban. 2017. El pretérito perfecto compuesto con valor aorístico en el habla urbana de Granada. In Pretérito perfecto simple y pretérito perfecto compuesto en español: Uso y gramatización. Edited by Susana Azpiazu and Carmen Quijada Van den Berghe. Special Issue, Orillas. vol. 6, pp. 455-70. Available online: http://orillas.cab.unipd.it/orillas/articoli/numero_6/05Montoro_astilleros.pdf (accessed on 4 January 2018).

Moreno Burgos, Juan. 2015. El pretérito perfecto compuesto en el ámbito hispánico. Anuario de Letras. Lingüística y Filología III: 87-130. [CrossRef]

Palacios Alcaine, Azucena. 2005. La influencia del quichua en el español andino ecuatoriano. In Variedades lingüísticas y lenguas en contacto en el mundo de habla hispana. Edited by C. Ferrero and N. Lasso-von Lang. Bloomington: AuthorHouse, pp. 44-52.

Palacios Alcaine, Azucena. 2006. Variedades del español hablado en América: Una aproximación educativa. In Las lenguas españolas: un enfoque filológico. Edited by Elena Miguel. Madrid: MEC, pp. 175-96.

Palacios Alcaine, Azucena. 2007. Cambios lingüísticos de ida y vuelta: Los tiempos del pasado en la variedad emergente de los migrantes ecuatorianos en España. Revista Internacional de Lingüística Iberoamericana 2: 109-25.

Pfänder, Stefan, and Azucena Palacios A. 2013. Evidencialidad y validación en los pretéritos del español andino ecuatoriano. Círculo de Lingüística Aplicada a la Comunicación 54: 65-98. [CrossRef]

RAE, and ASALE. 2009. Nueva gramática de la lengua española. Madrid: Espasa, p. 1721.

Rodrigues Parrihna, Silvia. 2014. Valores pragmáticos y discursivos en el uso del pretérito perfecto compuesto en el español de Buenos Aires. In Formas simples y compuestas de pasado en el verbo español. Edited by Susana Azpiazu. Lugo: Axac, pp. 103-15.

Rodríguez Louro, Celeste. 2009. Perfect Evolution and Change: A Sociolinguistic Study of Preterit and Present Perfect Usage in Contemporary and Earlier Argentina. Ph.D. thesis, The University of Melbourne, Melbourne, Australia. Available online: https://minerva-access.unimelb.edu.au/handle/11343/35140 (accessed on 30 December 2017).

Serrano, María José. 1994. Del pretérito indefinido al pretérito perfecto: Un caso de cambio y gramaticalización en el español de Canarias y Madrid. Lingüística Española Actual 16: 37-57.

Soto, Guillermo. 2014. El pretérito perfecto compuesto en el español estándar de nueve capitales americanas: Frecuencia, subjetivización y deriva aorística. In Formas simples y compuestas de pasado en el verbo español. Edited by Susana Azpiazu. Lugo: Axac, pp. 131-46.

Squartini, Mario, and Pier Marco Bertinetto. 2000. The simple and Compound Past in Romance languages. In Tense and Aspect in the Languages of Europe. Edited by Dahl Östen. Berlin: DeGruyter, pp. 403-39.

(C) 2019 by the author. Licensee MDPI, Basel, Switzerland. This article is an open access article distributed under the terms and conditions of the Creative Commons Attribution (CC BY) license (http://creativecommons.org/licenses/by/4.0/). 